\title{
The EBR-II X501 Minor Actinide Burning Experiment
}

\section{ANS: Nuclear Fuel and Structural Material Embedded Topical}

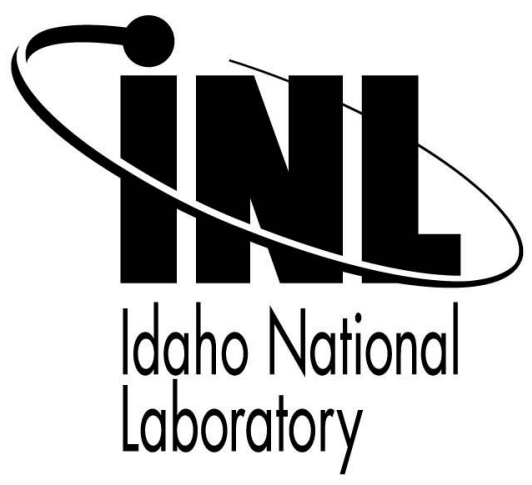

\section{June 2008}

This is a preprint of a paper intended for publication in a journal or proceedings. Since changes may be made before publication, this preprint should not be cited or reproduced without permission of the author. This document was prepared as an account of work sponsored by an agency of the United States Government. Neither the United States Government nor any agency thereof, or any of their employees, makes any warranty, expressed or implied, or assumes any legal liability or responsibility for any third party's use, or the results of such use, of any information, apparatus, product or process disclosed in this report, or represents that its use by such third party would not infringe privately owned rights. The views expressed in this paper are not necessarily those of the United States Government or the sponsoring agency. 


\title{
The EBR-II X501 Minor Actinide Burning Experiment
}

\author{
M. K. Meyer ${ }^{1}$, S.L. Hayes ${ }^{1}$, W. J. Carmack ${ }^{1}$, and H. Tsai ${ }^{2}$ \\ Idaho National Laboratory \\ P.O. Box 1625, Idaho Falls, Idaho 83403-2528 \\ ${ }^{2}$ Argonne National Laboratory \\ 9700 S. Cass Ave., Argonne, Illinois 60439-4803
}

\section{Introduction}

The X501 experiment was conducted in EBR-II as part of the IFR (Integral Fast Reactor) program to demonstrate minor actinide burning through the use of a homogeneous recycle scheme. The X501 subassembly contained two metallic fuel elements loaded with relatively small quantities of americium and neptunium. Interest in the behavior of minor actinides (MA) during fuel irradiation has prompted further examination of existing X501 data, and generation of new data where needed in support of the U.S. waste transmutation effort. The X501 experiment is one of the few minor actinide-bearing fuel irradiation tests conducted worldwide and knowledge can be gained by understanding the changes in fuel behavior due to addition of MA's. Of primary interest are the affect of the MA's on fuel-cladding-chemical-interaction, and the redistribution behavior of americium. The quantity of helium gas release from the fuel and any effects of helium on fuel performance are also of interest. It must be stressed that information presented at this time is based on the limited PIE conducted in 1995-1996, and currently represents a set of observations rather than a complete understanding of fuel behavior.

The original concept of the integral fast reactor (IFR) incorporated a passively safe reactor design with on-site fuel recycling ${ }^{\mathrm{i}}$. The IFR process utilized pyroprocessing of metallic fuel to separate $\mathrm{U}, \mathrm{Pu}$, and the minor actinides (Am, Np, and $\mathrm{Cm}$ ) from the non-actinide constituents. The actinides are reintroduced into the fuel and re-irradiated. Spent IFR fuel was expected to contain low levels of the minor actinides because the hard neutron spectrum should transmute these isotopes as they are produced. This opens the possibility of using an IFR to transmute actinide waste from spent light water reactor (LWR) fuel. Elimination of actinides from spent LWR fuel, which is destined for the high level waste (HLW) repository, would greatly reduce the amount of long-lived radioactive material requiring isolation of $10 \sim$ years or more ${ }^{\mathrm{ii}}$,iii. Reducing the levels of actinides in HLW would make the performance criteria of the repository easier to attain. A standard IFR fuel was based on the alloy $\mathrm{U}-20 \% \mathrm{Pu}-10 \% \mathrm{Zr}$ (in weight percent). The metallic fuel system eases the requirements for reprocessing methods and enables the minor actinide metals to be incorporated into the fuel with simple modifications to the basic fuel casting process. The nominal fuel composition used in this experiment is $\mathrm{U}-20.3 \% \mathrm{Pu}-10.0 \% \mathrm{Zr}-2.1 \% \mathrm{Am}-1.3 \% \mathrm{~Np}$ and is based on a concept where the standard IFR fuel is fabricated with Pu extracted from spent LWR fuel which has cooled 10 years. The LWR fuel is then envisioned to have gone through a reprocessing scheme during which the minor actinides accompany the $\mathrm{Pu}$ through the processing steps. About $0.12 \mathrm{wt} \%$ of $\mathrm{Cm}$ would also be present, but the radiation protection difficulties created by handling $\mathrm{Cm}$ outside of a hot cell and the low alloying content eliminated $\mathrm{Cm}$ from inclusion in these experiments. In this paper we report the initial casting experience of IFR fuel containing minor actinides, the irradiation conditions for the X501 experiment, and a summary of the post irradiation examination of the two MA bearing pins of the X501 experiment.

\section{X501 Fabrication}

Metallic U-20\%Pu-10\%Zr (by weight) nuclear fuel was differential pressure injection cast into a vitreous silica mold with the addition of two minor actinides, $2.1 \% \mathrm{Am}$ and $1.3 \% \mathrm{~Np}$. Three full length fuel slugs $(4.3 \mathrm{~mm} \times 340 \mathrm{~mm}$ ) were successfully cast incorporating both $\mathrm{Np}$ and Am. No unusual macrosegregation of the major constituents was observed. About $60 \%$ of the initial Am and $100 \%$ of the $\mathrm{Np}$ charge was present in the as-cast fuel. Am loss was attributed to volatile contaminants in the feed stock and evaporation at the casting temperature $\left(1465^{\circ} \mathrm{C}\right)$. Microstructural and microchemical characterization of the as-cast fuel along with bulk chemical analyses are reported. Details of the casting process and 
resulting microstructure are given in reference ${ }^{\mathrm{iv}}$. Considerable americium was lost due to volatilization during the fabrication process, which was not designed for use with Am-bearing alloys.

\section{Materials and methods}

The typical injection casting temperature for $\mathrm{U}-20 \% \mathrm{Pu}-10 \% \mathrm{Zr}$ is $1465^{\circ} \mathrm{C}$. The superheat is about $150^{\circ} \mathrm{C}$ which is required to fill the molds which are $4.3 \mathrm{~mm} \times 460 \mathrm{~mm}$. The feed stock used was elemental metallic $\mathrm{Np}, \mathrm{U}, \mathrm{Zr}$, and $\mathrm{Pu}$. The Am feed stock was a metallic alloy of Pu-20\%Am. Potential concerns in casting metallic fuels with minor actinide elements were the wide variations in vapor pressure between Am, $\mathrm{Np}, \mathrm{Pu}$ and $\mathrm{U}$, and the very highly negative free energy of oxide formation for Am. Over the range of melting temperatures, Am has nearly three orders of magnitude higher vapor pressure than $\mathrm{Pu}$, and five orders of magnitude higher than $\mathrm{Np}$ or $\mathrm{U}^{\mathrm{v}, \mathrm{vi}}$. This implies that a significant amount of Am could be lost as a vapor at casting temperatures. The potential for Am oxidation arises because $\mathrm{AmO}$ is considerably more stable than $\mathrm{ZrO}, \mathrm{UO}$, or $\mathrm{PuO}$, at all temperatures ${ }^{\mathrm{vii}}$. It is possible that the Am could become part of the casting dross and not be incorporated into the fuel. The challenge becomes how to cast these fuel alloys with minimum Am loss under the characteristic range of processing conditions.

In order to reduce Am loss through evaporation and reaction with oxygen, the time at elevated temperatures, where the Am evaporation and reaction rates are high, should be constrained to as short as possible. The fabrication facility (the Experimental Fuels Laboratory at Argonne National Laboratory in Idaho) was therefore modified to include a bucket device with a lid allowing the Pu-Am feed material to be added to molten fuel within the crucible late in the melt cycle to minimize the time at temperature.

Furthermore, the atmosphere above the melt was extremely pure $\operatorname{Ar}(99.9997 \%)$, containing less than 1.5 ppm oxygen. The elements $\left(\mathrm{U}, \mathrm{Zr}, \mathrm{Np}\right.$ and some $\mathrm{Pu}$ ) were loaded into a $\mathrm{Y}_{2} \mathrm{O}_{3}$ coated graphite crucible and induction heated under an Ar atmosphere. After reaching a temperature of $1495^{\circ} \mathrm{C}$, the melt was stirred causing the temperature to drop to $1465^{\circ} \mathrm{C}$. The melt was reheated and stirred again. At this point, the $\mathrm{Pu}-$ Am was added to the crucible via the bucket which sat next to and above the crucible inside the furnace. When the Pu-Am feed stock was added, "sparks" were observed emerging from the melt. Casting proceeded and three full-length pins were successfully cast into $\mathrm{ZrO}$, coated quartz molds. The entire crucible charge was consumed during casting and the pins were removed from the molds. Two pins were encapsulated and made ready for in-reactor (EBR-II) testing while the remaining pin was sacrificed for metallographic and chemical characterization.

\section{Fabrication Results}

Figure 1 shows optical images of fuel cross-sections taken from locations near the top and bottom of a pin from the same casting batch as the irradiated fuel pins. Figure 1(a) was taken from the top section of the fuel pin, and shows the inhomogeneous structure typical of $\mathrm{U}-\mathrm{Pu}-\mathrm{Zr}$ fuel produced by this casting method. Figure 1(b) shows a micrograph of a section taken from the lower part of the fuel pin, in a region where cooling is slower after solidification due to proximity with the furnace internals.
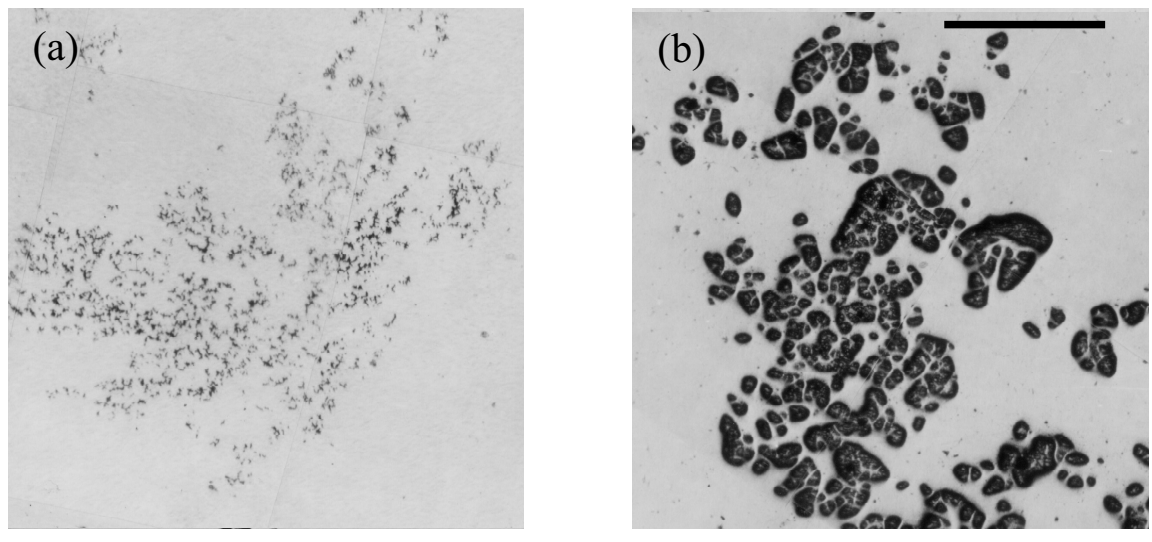
Figure 1. Microstructure of as-cast fuel pin. (a) top section, (b) lower section. Fiducial Bar $=\mathbf{5 0 0}$ $\mu \mathrm{m}$.

\section{Bottom of fuel}

The as-cast microstructure at the bottom of the fuel is illustrated by the transverse view in Figure 2(a). The salient features are a darker gray, irregularly shaped phase in a light matrix. Two areas of mold-melt interaction are arrowed, A and B. At higher magnification (Figure 3) the irregular phase is found to be composed of a collection of two different smaller particles. Wavelength dispersive spectroscopy (WDS) analysis shown in Figure 2(b) indicates that the distribution of americium and neptunium is uniform across the section and the light colored smaller $(5-15 \mu \mathrm{m})$ particles are primarily composed of $\mathrm{Zr}$ while the larger dark particles $(30-60 \mu \mathrm{m})$ have a widely variable composition but contain at most only about $20 \% \mathrm{Zr}$. Very fine $(0.5-1.5 \mu \mathrm{m})$ round particles termed "beads" were observed internal to the Zr-rich particles and found to be basically composed of U. Examination of the matrix by WDS (wavelength dispersive spectroscopy) revealed that the major constituents did not vary radially across the section. A few high Am peaks were detected, but could not be associated with any particular feature.
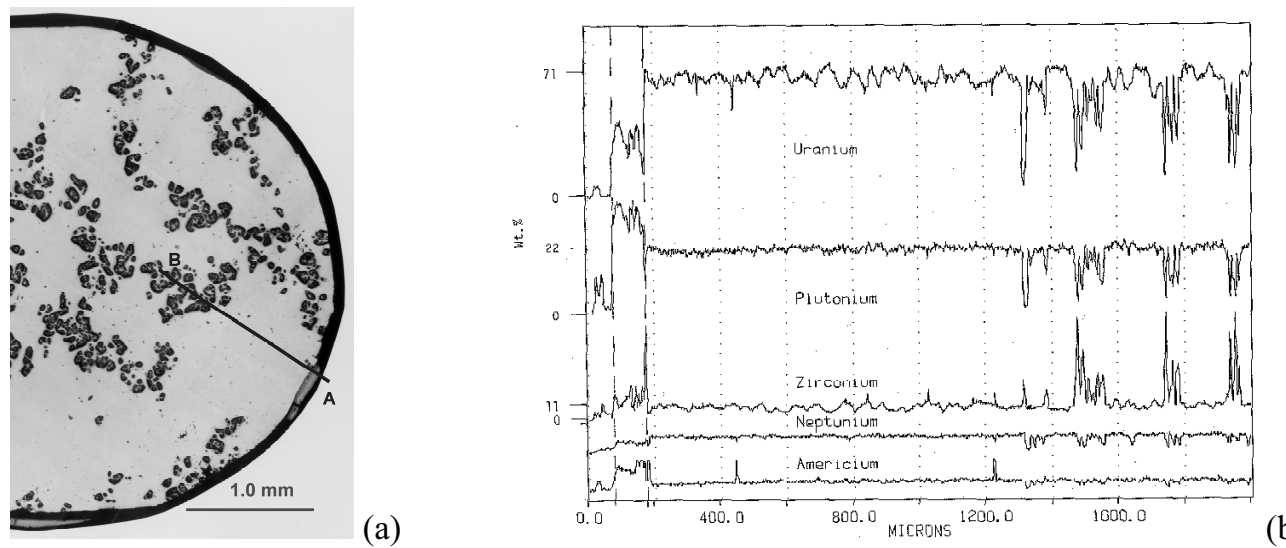

(b)

Figure 2. (a) Transverse optical micrograph of the bottom of the as-fabricated $\mathrm{U}-\mathbf{2 0 . 3 \% P u - 1 0 . 0 \%}$

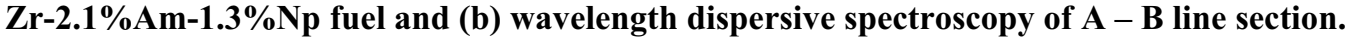

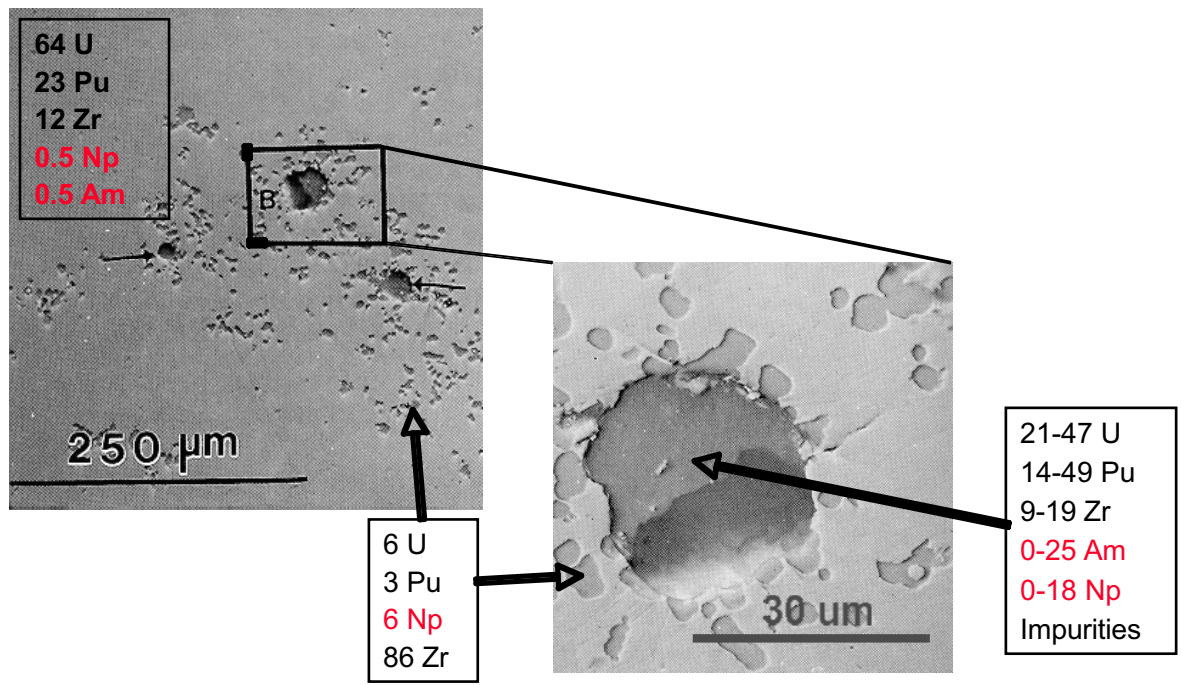

Figure 3. Individual features in bottom section of the fuel. (a) Secondary electron image of the two particle types; (b) higher magnification secondary electron image of area $B$. 


\section{Top of fuel}

As seen in Figure 4(a), the microstructures at the center and top sections of the fuel are analogous. The $\mathrm{Zr}$-rich regions were not collections of irregular particles as seen at the bottom of the fuel, rather the $\mathrm{Zr}$ was present mainly in a dendritic morphology. No unusual mold-melt interaction layers were observed and the matrix was uniform in composition as detected by WDS shown in Figure 4(b).

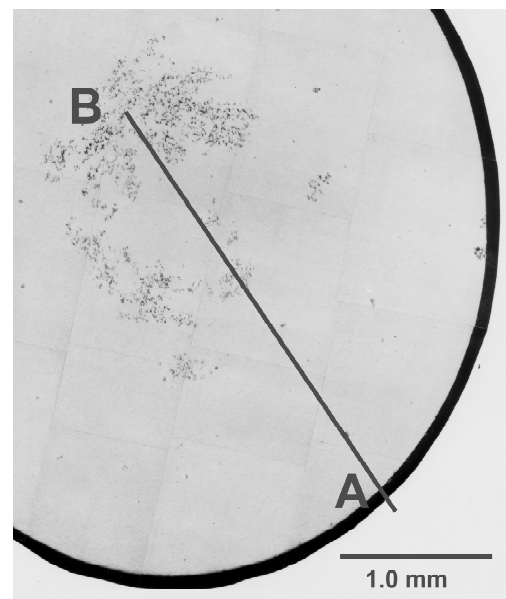

(a)

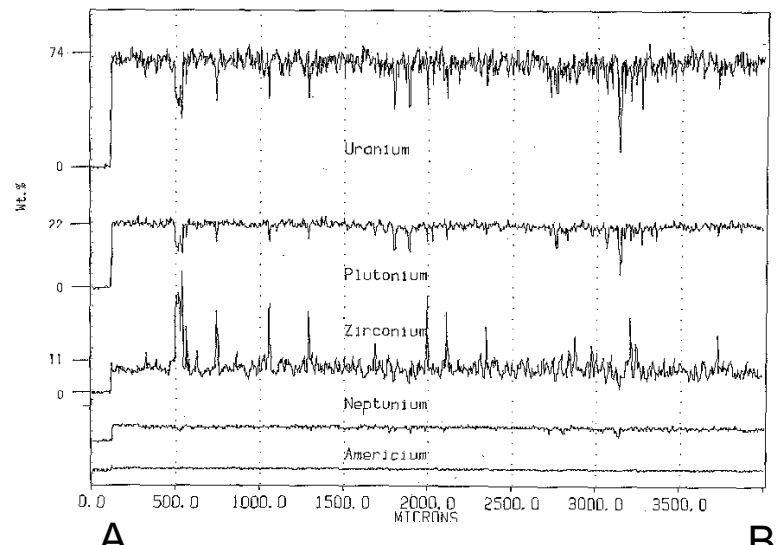

Figure 4. (a) Transverse optical micrograph of the top of the as-fabricated $\mathrm{U}-20.3 \% \mathrm{Pu}-10.0 \% \mathrm{Zr}$ $2.1 \% \mathrm{Am}-1.3 \% \mathrm{~Np}$ fuel casting and (b) wavelength dispersive spectroscopy of $\mathrm{A}-\mathrm{B}$ line section.

\section{Bulk chemistry}

Sections from the top, center and bottom of the fuel were chemically analyzed and the results are given in Table 1. The U, $\mathrm{Pu}, \mathrm{Zr}$, and $\mathrm{Np}$ levels are axially uniform, within experimental error, while the Am level is low in the bottom section of the fuel. Some Am was lost as denoted by the low measured concentrations. Also, there is a notable increase in the amount of Si present in the bottom section versus the top and center sections. Increased Si levels are most likely due to the quartz (SiO,) molds. The $\mathrm{ZrO}$, wash does not completely protect the molds from the molten fuel and some interaction occurs. Mold-melt interactions are most severe at the bottom of the molds because the mold ends are submerged in the melt for the entire casting time and fuel located at the bottom of the slug cools last after injection casting.

Table 1. Bulk chemical analysis of as-fabricated X501 fuel castings (in wt\%).

\begin{tabular}{|c|c|c|c|c|}
\hline Element & \multicolumn{4}{|c|}{ Location } \\
\hline & Top & Center & Bottom & Average \\
\hline $\mathbf{U}$ & 67.31 & 65.95 & 68.02 & 66.06 \\
\hline $\mathbf{P u}$ & 19.51 & 21.24 & 19.85 & 20.2 \\
\hline $\mathbf{Z r}$ & 9.12 & 9.22 & 9.02 & 9.12 \\
\hline $\mathbf{A m}$ & 1.33 & 1.32 & 1.03 & 1.23 \\
\hline $\mathbf{N p}$ & 1.39 & 1.19 & 1.36 & 1.31 \\
\hline $\mathbf{S i}$ & 0.179 & 0.179 & 0.422 & 0.26 \\
\hline $\mathbf{A l}$ & 0.144 & 0.077 & 0.045 & 0.0887 \\
\hline $\mathbf{C a}$ & 0.189 & 0.0067 & 0.0046 & 0.0668 \\
\hline $\mathbf{M g}$ & 0.017 & 0.0028 & 0.0065 & 0.0088 \\
\hline $\mathbf{C r}$ & 0.0042 & 0.0018 & 0.0015 & 0.0025 \\
\hline $\mathbf{M n}$ & 0.0012 & 0.0009 & 0.0008 & 0.001 \\
\hline $\mathbf{F e}$ & 0.0018 & 0.0009 & 0.0007 & 0.0011 \\
\hline $\mathbf{N i}$ & 0.004 & 0.004 & 0.004 & 0.004 \\
\hline
\end{tabular}


A representative transverse section from a $\mathrm{U}-20 \% \mathrm{Pu}-1 \mathrm{O} \% \mathrm{Zr}$ fuel slug without minor actinide additions is shown in Figure 5. In this electron image the dark phase is highly rich in $\operatorname{Zr}(\mathrm{N} 80 \%$ by weight) akin to the $\mathrm{Zr}$-rich regions observed in the minor actinide bearing fuel; however, they differ morphologically. In conventional ternary fuel the $\mathrm{Zr}$-rich regions consisted of contiguous globular features, but in this casting these "globular" regions were broken up into numerous small particles at the bottom of the fuel. This difference in shape could be the result of impurities in the melt.

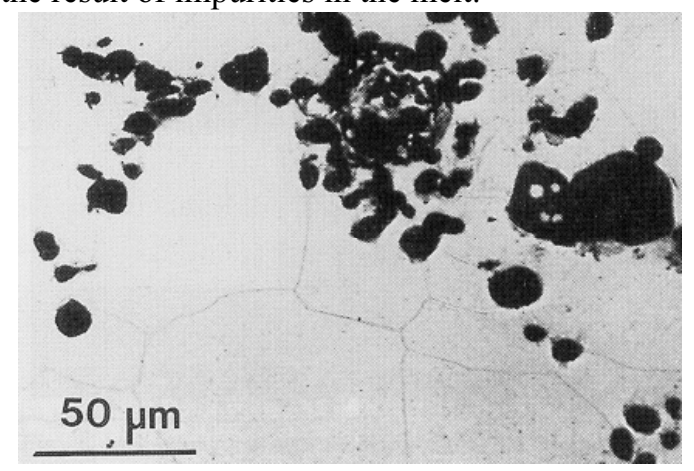

Figure 5. Micrograph of as-fabricated U-20Pu-10Zr.

Conventional U-Pu-Zr fuel contains at most about $300 \mathrm{ppm}$ Si while the fuel in X501 experiment contained up to 14 times more $\mathrm{Si}$. The microchemical analysis revealed impurity segregation in the larger particles (fig. 3 and table 11, i.e., $\mathrm{Cl}, \mathrm{Ca}, \mathrm{Si}$, etc. This analysis is insensitive to light elements such as $\mathrm{C}, 0$, and $\mathrm{N}$ and bulk chemical analysis of these elements was not available. Investigations into the $\mathrm{U}-\mathrm{Zr}$ phase diagram ${ }^{\text {viii }}$ uncovered significant changes in the phase relations at the U-rich end of the phase diagram due to small amounts of oxygen. It is reasonable to expect that the high Si content in the bottom of the fuel would influence the morphology of the $\mathrm{Zr}$-rich phase. Further investigations into the phase relationships in fuel containing impurities, such as $\mathrm{Si}, \mathrm{O}, \mathrm{C}, \mathrm{N}$, and $\mathrm{Ca}$, need to be done to determine what influence they have on microstructure and phase relationships. The sparking observed during the minor actinide addition was found to be small droplets of the melt emerging from the crucible. Examinations of the inner furnace surfaces and exhaust lines after the casting revealed increased alpha activity from the Am. The "sparks" were induced by two factors: contaminants in the Pu-Am feed stock with low boiling temperatures and the high vapor pressure of Am at the casting temperature $1465^{\circ} \mathrm{C}$. The Pu-Am feed stock contained - 3 at $\% \mathrm{Ca}$ and $\mathrm{Mg}$ (2000 ppm by weight). Both of these elements boil below $1440^{\circ} \mathrm{C}$ causing the melt pool to become agitated. Secondly, the equilibrium vapor pressure of $\mathrm{Am}$ at $1465^{\circ} \mathrm{C}$ is 3.3 Torr which yields an evaporation rate of about $0.1 \mathrm{~g} / \mathrm{cm}$ 's using the Knudsen-Langmuir equation for pure Am in a vacuum. Considering a crucible with a surface area of $50 \mathrm{~cm}$, an evaporation rate of about $0.1 \mathrm{~g} / \mathrm{cm}^{2} \mathrm{~s}$ yields a loss of $5 \mathrm{~g}$ per second in a perfect vacuum. The present controls on the casting furnace preclude an exact measurement or control of the pressure during casting. A partial vacuum existed prior to placing the molds in the melt. The high vapor pressure of Am at the casting temperature cannot be altered, but large Am losses can be mitigated. Experimentation employing lower superheats would help but may not be feasible because a lower viscosity melt might not completely fill the molds. The total amount of Am lost could also be reduced by further limiting time at temperature and casting under more positive pressure.

\section{X501 Experiment Irradiation}

The X501 fuel slugs were fabricated into two EBR-II MkIV configuration fuel pins. The two MAbearing pins were inserted into a standard EBR-II subassembly with the remainder of the fuel element locations filled with U-10Zr driver fuel. The X501 subassembly was inserted into EBR-II in the central core region, as shown in Figure 6, beginning in February 1993, and withdrawn just prior to EBR-II shutdown in August 1994. Total irradiation time was 339 EFPD's. Burnup, calculated on the basis of REBUS/RCT/ORIGEN calculations ${ }^{\mathrm{ix}}$ was $7.6 \% \mathrm{HM}$ with transmutation of $9.1 \%$ of ${ }^{241} \mathrm{Am}$. Peak linear heat generation rate was estimated to be $45 \mathrm{~kW} / \mathrm{m}(13.7 \mathrm{~kW} / \mathrm{ft})$ and peak fuel centerline and cladding inner surface temperatures were approximately $700^{\circ} \mathrm{C}$ and $540^{\circ} \mathrm{C}$, respectively. The chemical analysis and physical attributes of the two X501 fuel elements are given in Table 2. 


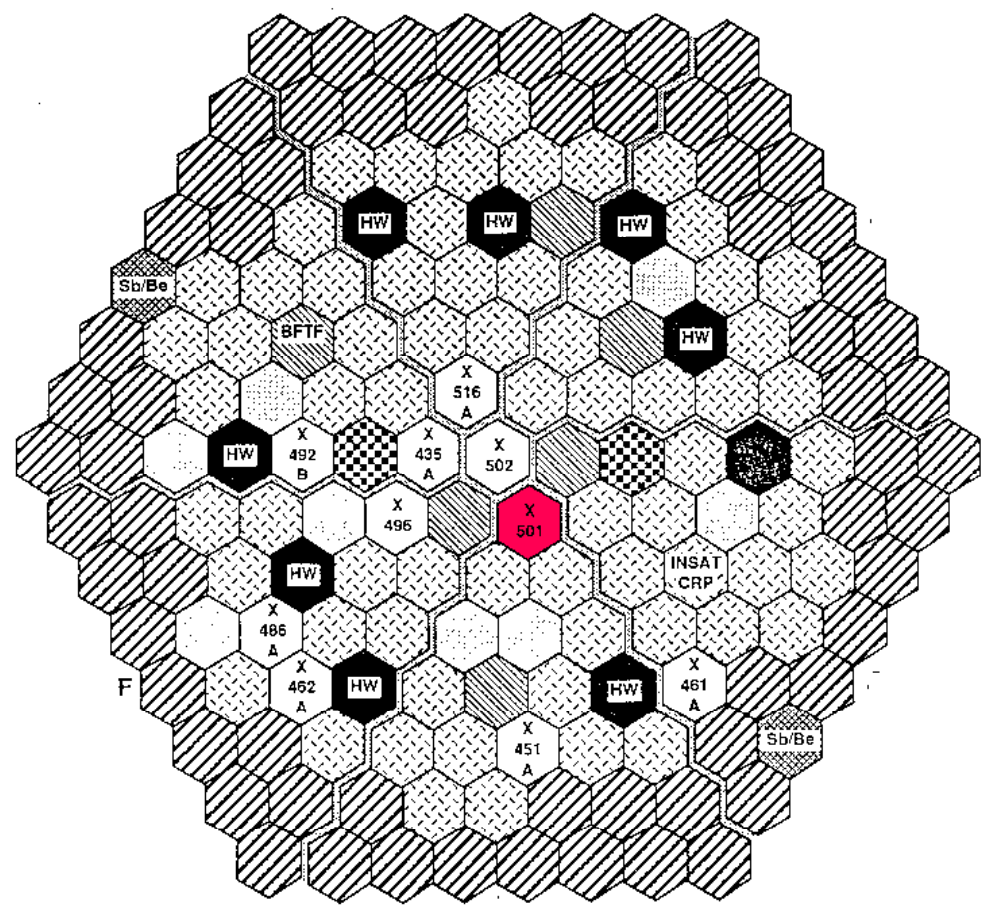

Figure 6. X501 experiment location in EBR-II.

Table 2. Attributes of X501 minor actinide bearing fuel elements

\begin{tabular}{|l|l|}
\hline $\begin{array}{l}\text { Composition (average analyzed } \\
\text { wt\%) }\end{array}$ & U-20.2Pu-9.1Zr-1.2Am-1.3Np \\
\hline Major impurities (average wt\%) & $\begin{array}{l}\text { Si:0.26, Al:0.089, Ca:0.067, } \\
\text { Cr:0.0025, Mg:0.009, Fe:0.001, } \\
\text { Mn:0.001 }\end{array}$ \\
\hline U-235 enrichment (nominal) & $60 \%$ \\
\hline Fuel mass & $77.5 \mathrm{~g}$ \\
\hline Fuel length & $34.3 \mathrm{~cm}(13.5 \mathrm{in})$. \\
\hline Element length (nominal) & $74.9 \mathrm{~cm}(29.5 \mathrm{in})$. \\
\hline Cladding type & $\mathrm{HT}-9 \mathrm{steel}$ \\
\hline Cladding OD & $5.84 \mathrm{~mm}(0.230$ in.) \\
\hline Cladding wall & $0.457 \mathrm{~mm}(0.018$ in.) \\
\hline Slug diameter & $4.27 \mathrm{~mm}(0.168$ in.) \\
\hline Plenum volume & $7.1 \mathrm{~cm} 3$ \\
\hline Plenum gas & $75 \mathrm{He}-\mathrm{Ar}$ \\
\hline Smeared density & $75 \%$ \\
\hline $\begin{array}{l}\text { Fuel slug density, } \\
\% \text { theoretical }\end{array}$ & $99.5 \%$ \\
\hline
\end{tabular}

\section{X501 Postirradiation Examination}

A partial postirradiation examination was completed on X501, including gamma scanning, optical microscopy, microprobe analysis, and metallography. The post irradiation examination completed 
indicated that the minor additions of $\mathrm{Am}$ and $\mathrm{Np}$ to the $\mathrm{U}-\mathrm{Pu}-\mathrm{Zr}$ matrix did not effect the irradiation behavior of the fuel.

Gamma scans, example shown in Figure 7, showed normal metallic fuel fission product behavior, with ${ }^{137} \mathrm{Cs}$ alloying with the bond sodium and migrating to the region near the top of the fuel slug.

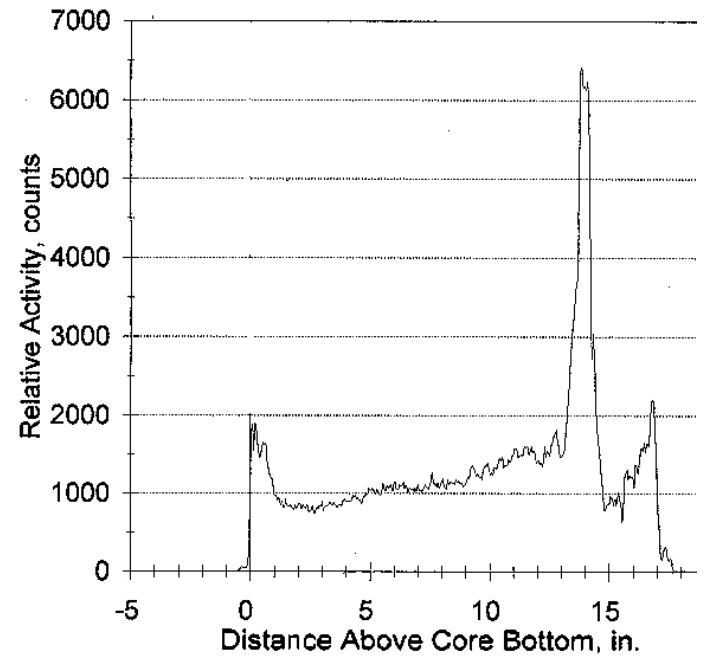

Figure 7. Example Cs-137 gamma scan of a X501 pin.

A microscopic examination of the inside cladding surface was made to determine if the inclusion of the MA's to U-Pu-Zr fuel has an effect on FCCI (Fuel-Cladding Chemical Interaction). The HT-9 cladding used for the X501 experiment is also the reference cladding for U.S. transmuter fuel. Optical microscopy (Figure 8) showed no evidence of reaction layer formation on the inner cladding wall or the outer surface of the fuel slug. A gap is visible between the fuel and the cladding wall at all locations. These preliminary results indicate that under typical metal fuel operating conditions, FCCI (fuel-cladding-chemicalinteraction) of HT-9 is not strongly affected by small amounts of americium or neptunium.

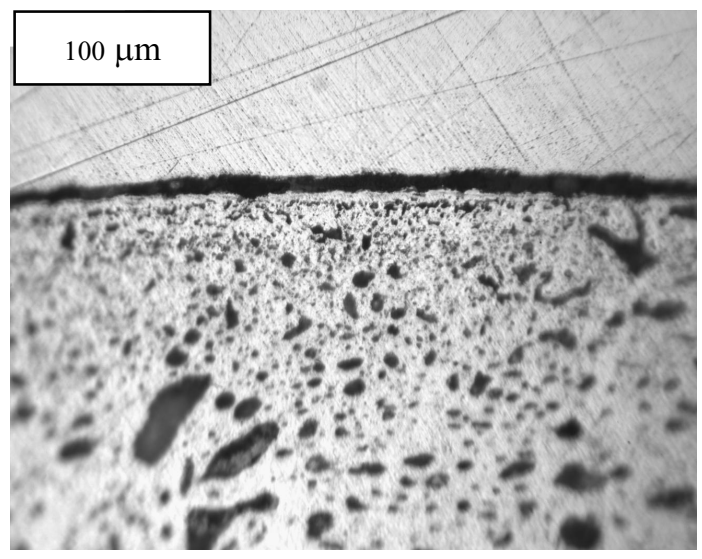

Figure 8. Optical micrograph of fuel/cladding interface.

Shown in Figure 9(a) is a postirradiation optical micrograph of a cross section near the center of element G582. The fuel shows a microstructure typical of U-20Pu-10Zr, where constituent radial redistribution has resulted in the formation of three microstructural zones within the fuel. Figure 9(b) is a comparison of the WDS traces of neptunium, americium, zirconium, plutonium, and uranium across the section shown in Figure 9(a). The outer zone, near the cladding, is enriched in zirconium, the intermediate 
zone is zirconium depleted, and the central zone is enriched in zirconium and depleted in uranium.

Plutonium content remains relatively uniform. Americium appears in the WDS traces as features with high elemental concentrations, generally depleted in $\mathrm{U}, \mathrm{Pu}$, and $\mathrm{Zr}$ (the other major elemental constituents). The morphology of the americium-rich phases cannot be determined from existing micrographs, and other elemental constituents, such as fission product and impurity elements were not analyzed during the examination. Comparison of the preirradiation and postirradiation WDS line scans suggests that the americium-rich features formed during irradiation. Americium is present only in the uranium-depleted central and outer zones, indicating that americium migration has occurred along with the migration of uranium and zirconium. Local radial redistribution of americium to the cladding inner wall does not occur; however these results do not rule out the possibility of condensation of americium in the plenum region above the fuel column.
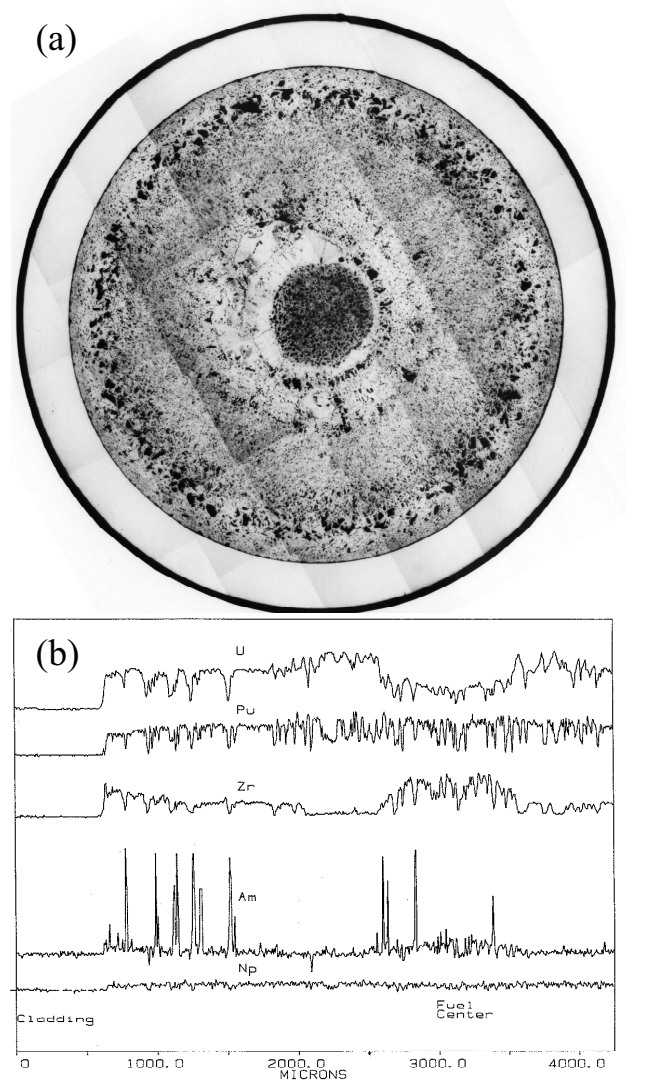

Figure 9. (a) Postirradiation optical image of MA-bearing fuel. (b) WDS line scans showing distribution of actinides and $\mathrm{Zr}$.

Plenum gas sampling results were combined with ORIGEN calculations to estimate the fission gas and helium release rates from the fuel. Results are shown in

Table 3. Helium generation is principally due to a sequence of neutron capture by ${ }^{241} \mathrm{Am}$, and subsequent decay of the ${ }^{242} \mathrm{Cm}$ product to ${ }^{238} \mathrm{Pu}$ by alpha particle emission. The amount of He introduced as plenum fill gas was estimated based on pressure ratios between fill gas and the quantity of radioactive Xe tag gas measured by counting Xe activity. Based on these estimates, it appears that approximately $90 \%$ of the helium gas produced was released to the plenum. Fission gas release was $79 \%$, typical of U-Pu-Zr fuel at this burnup. 
Table 3. X501 gas production and release.

\begin{tabular}{|l|l|}
\hline BOL $^{\mathbf{2 4 1}}$ Am content & $0.972 \mathrm{~g}$ \\
\hline EOL ${ }^{\mathbf{2 4 1}}$ Am content & $0.884 \mathrm{~g}$ \\
\hline${ }^{241}$ Am transmutation & $0.088 \mathrm{~g}(9.1 \%)$ \\
\hline Measured He release & $3.1 \mathrm{~cm}^{3}$ \\
\hline Calculated He inventory, 1 yr. decay & $3.4 \mathrm{~cm}^{3}$ \\
\hline He release & $90 \%$ \\
\hline FG release & $79 \%$ \\
\hline
\end{tabular}

The generation of helium gas during transmutation of ${ }^{241} \mathrm{Am}$ is a significant issue that must be considered in the design of transmuter fuel. In fuels with high americium content, helium generation is principally due to neutron capture by ${ }^{241} \mathrm{Am}$ and subsequent alpha decay of ${ }^{242} \mathrm{Cm}$ to ${ }^{238} \mathrm{Pu}$. There are three known experiments involving transmutation of ${ }^{241} \mathrm{Am}$. Helium release results from two, the EFTTRA-T4 test and the SUPERFACT-1 experiment have been previously published. Some data on helium generation is available for each experiment, and results are presented in Table 4, along with ORIGEN calculations for the U.S. Na-cooled point design and X501 data. The quality and completeness of data vary for each experiment; therefore the results of this analysis contain a good deal of uncertainty, and do not provide a good basis for extrapolation. A rule-of-thumb for estimating helium production from americium for the U.S. transmuter design, based on the results in Table 4 and calculations of compositions ranging from 6-40 $\mathrm{wt} \%{ }^{241} \mathrm{Am}$ is $50 \mathrm{ml}$ He per gram of transmuted americium. The wide range of possible fuel compositions leads to a wide range in the potential for helium production. Helium production is likely to be the most important fuel design consideration for transmutation scenarios with high MA content.

Table 4. Data and calculations for He production in ${ }^{241} \mathrm{Am}$-bearing fuels.

\begin{tabular}{|c|c|}
\hline Experiment & $\begin{array}{c}\text { Specific He generation } \\
\left(\mathrm{ml} \text { per g gram }{ }^{241} \text { Am transmuted }\right)\end{array}$ \\
\hline X501 & $38.6-44.8$ \\
\hline SUPERFACT-1 & $33.3-63.4$ \\
\hline EFTTRA-T4 & $44.8-59.9$ \\
\hline Na point design & 58.1 \\
\hline
\end{tabular}

\section{Summary}

The U.S. fast reactor fuel program demonstrated the use of americium-bearing fuel in the early 1990's. Three full length fuel pins containing minor actinide additions were successfully cast with no unusual macrosegregation of major constituents observed. The Zr-rich phase displayed an unconventional morphology in the bottom section of the castings appearing as a dense collection of small particles instead of the usual contiguous globular shape. This is probably the result of significant levels of impurities present. Approximately $40 \%$ of the initial Am charge was lost during casting due to volatile impurities $(\mathrm{Ca}$ and $\mathrm{Mg}$ ) in the $\mathrm{Am}-\mathrm{Pu}$ feed stock and through evaporation. Limited post-irradiation examination results from the X501 experiment indicate that the addition of $1.2 \mathrm{wt} . \%$ of americium did not alter the behavior of metallic U-Pu-Zr fuel.

\section{Acknowledgments}

The authors wish to acknowledge C.L. Trybus for preparing the X501 experiment for irradiation. The work presented in this report represents the efforts of many researchers, technicians, as well as the efforts of EBR-II operations personnel. Their efforts should be recognized. 
Work supported by the U.S. Department of Energy, Office of Nuclear Energy, Science, and Technology (NE), under DOE-NE Idaho Operations Office Contract DE-AC07-05ID14517.

\section{References}

i. Y.I. Chang, Nucl. Techn. 88 (1989) 129.

ii. A.G. Croff, C.W. Forsberg and S.B. Ludwig, Proc. From ANS Meeting, November 1990, Washington DC, CONP-901101, p. 144.

iii. Y.I. Chang and C.E. Till, Proc. from Annual WATTec Conference and Exhibition, February 1989 Knoxville, TN, CONF-890218-13, p. 129.

iv. C.L. Trybus, J.E. Sanecki, S.P. Henslee, "Casting of Metallic Fuel Containing Minor Actinide Additions," J. Nuc. Mat., 204 (1993) 50-55.

v. N.D. Erway and O.C. Simpson, J. Chem. Phys. 18 (1950) 953.

vi. C.B. Alock, V.P. Itkin and M.K. Horrigan, The Canadian Metallurgical Quarterly 23(3) (1984) 309.

vii. E.H.P. Cordfunke and R.J.M. Konings (eds.), Thermochemical Data For Reactor Materials and Fission Products (North-Holland, Amsterdam, 1990).

viii. ST. Zegler, The Uranium-Rich End of the Uranium-Zirconium System, ANL-6055 (February 1962).

ix. R. McKnight, personal communication, Argonne National Laboratory (2001). 